Krismiaji, K., \& Surifah, S. (2020). Corporate governance, compliance level of IFRS disclosure and value relevance of accounting information - Indonesian evidence. Journal of International Studies, 13(2), 191-211. doi:10.14254/2071$8330.2020 / 13-2 / 14$

\title{
Corporate governance, compliance level of IFRS disclosure and value relevance of accounting information - Indonesian evidence
}

\author{
Krismiaji Krismiaji \\ Department of Accounting, Accounting Academy of YKPN, \\ Indonesia \\ xmiaji@gmail.com \\ Surifah Surifah \\ Department of Accounting, Universityof Technology Yogyakarta, \\ Indonesia \\ surifah.ifah@gmail.com
}

Abstract. This paper discusses the results of empirical research that investigates the effect of corporate governance (CG) and the level of compliance with mandatory disclosure of the International Financial Reporting Standards (IFRS) on the quality of accounting information produced by Indonesian companies. The research covers five years after full implementation of IFRS, namely from 2013 to 2017. The quality of information is proxy by using value relevance of accounting information which is measured by the Ohlson Price Model. The level of compliance of the IFRS disclosures is measured using the disclosure index (DIND) and CG is proxy by board independence (BIND), board size (BSIZE), audit committee independence (ACIND), audit committee size (ACSIZE), and management ownership (MAN). This study find that DIND and BSIZE have a positive effect on the value relevance of accounting information, both EPS and BVS, while BIND, ACIND, and MAN negatively affect the value relevance of EPS but have a positive effect on the value relevance of BVS. ACSIZE has a positive effect on the value relevance of EPS but also a negative effect on the value relevance of BVS. These results further justify the inconsistency of the results of previous studies that link IFRS adoption and the quality of accounting information by including compliance level variables to test the quality (relevant value) of accounting information produced by Indonesian companies.

Keywords: value relevance, corporate governance, level of compliance, Ohlson Price Model, Indonesia.

JEL Classification: G34, M41 


\section{INTRODUCTION}

This study investigates the effect of the level of compliance with mandatory disclosure of the International Financial Reporting Standards (IFRS) and corporate governance on the quality of accounting information. This study was motivated by the mixed results of several studies on the influence of IFRS adoption on information quality, some of which improved the quality of accounting information (Barth, Landsman, \& Lang. 2008; Covrig, DeFond, \& Hung 2007; Dumontier \& Raffournier 1998; Tarca 2004; Cuijpers \& Buijink 2005; Street, Gray, \& Bryant 1999; Daske, Hail, Leuz, \& Verdi 2008; Kim \& Shi 2007; Hung \& Subramanyam 2007; Landsman, Maydew, \& Thornock 2012), some of which reduce the quality of accounting information (Paananen, 2008; Paananen \& Lin, 2009) and some have no effect on the quality of accounting information (Beuselinck, Joos, \& Meulen 2007; Jeanjean and Stolowy 2008; Jarva \& Lantto 2010). Therefore, further research needs to be performed to find out the influence of IFRS adoption, the level of compliance with mandatory disclosure of the International Financial Reporting Standards (IFRS) post-IFRS full adoption in 2012, and of corporate governance on the quality of accounting information, especially the value relevance of this information.

Faithfulness and quality of financial reports have been of continuous interest for regulator bodies and other interest parties, particularly after accounting scandals which involve large and reputable corporations such as Enron, WorldCom, and Xerox. Several research (Byrne, 2002; Deakin and Konzelmann, 2004) report that accounting scandals have caused the introduction of corporate governance (CG) since company problems are often associated with insufficient CG practices. Companies' problems are often caused by the risks of corporate mismanagement and the conflicts of interest between the board and shareholders.

The outcome of corporate financial reporting depends on the accounting standards used as well as motivations and limitations faced by financial report compilers in complying with these standards (Pope and McLeay, 2011). Most countries have adopted International Financial Reporting Standards (IFRS), thus the latter became one of the most significant rules in the history of accounting. However, just relying on IFRS adoption alone is not enough for improvements in the quality of financial information if it is not accompanied by full agreement with the disclosure standards.

Hodgdon et al. (2008) focused on the significances of IFRS agreements to find that profit forecasting errors made by analysts were affect negatively the compliance level of disclosure standards. Bova and Pereira (2012) report a positive relationship between IFRS disclosure compliance with the increase in stock turnover in emerging countries with a lower level of rule implementation. Those findings indicate that IFRS adoption does not have an impact on quality improvement if it is not followed by full obedience with accounting standards. Yet, Pope and McLeay (2011) and Krismiaji, Aryani, and Hardjanto (2016) prove that the CG mechanism is expected to significantly affect financial reporting compliance with IFRS, especially in the countries with lower law enforcement, as in Indonesia. Brown (2011) also states that achieving benefit from IFRS relies on some factors such as regulatory and format backing for standards and the level of obedience and implementation monitoring.

The financial report quality and the IFRS adoption benefits also rely on the motivation power for financial reporting compliance (Juhmani, 2017). This motivation is very dependent on the enforcement framework. This framework is widely described in guidance to comprise all institutions and procedures used to certify agreement with the provisions, such as CG, auditors, regulators, and courts (IAS Regulation, 2014).

Reporting reflects the effectiveness of CG because it provides information transparency for both shareholders and other stakeholders (Juhmani, 2017). Verriest et al. (2013) state that high-quality disclosure is associated with strong CG. The level of disclosure generally increases when companies 
implement IFRS, and also, companies with high-quality CG further strengthen the quality of financial information disclosure. Forker (1992) asserts that CG processes such as independence of board improve monitoring of the corporate disclosure quality. Williamson (1982) also states that board independence results in increased transparency.

The audit committee is seen as an adequate means to improve the quality of financial information (United Nations Conference on Trade and Development, 2006). The presence of audit committees improve the quality of reports, disclosures, internal control systems, and in turn makes financial reports more reliable (Forker, 1992; Ho and Wong, 2001). The construction of company's share possession is also one of the important governance mechanisms. Makhija and Patton (2004) state that the degree and quality of corporate disclosure are the results of conflicts of interest between management, majority shareholders, and minority shareholders. With controlling power, the majority of shareholders can manipulate the degree of disclosure to maximize personal benefits, obtain benefits directly from the company or share value change in the stock market.

The CG mechanism is formed to certify that business managers work mainly to provide benefits to shareholders by increasing the firm's value. Supervisory institutions, both in established and developing market environments, which recognize the importance of the interests of shareholders protection, have issued a series of CG guidelines. In Indonesia, these guidelines include Ministerial Regulation No.01/MBU/2011 concerning the application of good corporate governance, Bank Indonesia Regulation Number 8/4/PBI/2006 concerning Good Corporate Governance for Commercial Banks, Booklets issued by the Forum for Corporate Governance in Indonesia (FCGI) of 2000 which contains corporate governance system, and the most recent one is The Indonesian Corporate Governance Manual published by the Financial Services Authority (FSA) in 2014.

Recently there has been a high awareness of the importance of CG in improving the quality of financial reporting. Yet, the effect of CG on the IFRS obedience has not been explored much, especially in developing countries and emerging capital markets. To the best of the researchers' knowledge, until now there has been limited research on IFRS compliance. Therefore, this research is intended to fill the literature gap on the impact of IFRS compliance and the CG on financial reporting quality, in terms of the value relevance of accounting quality. This research enriches CG literature. Three previous studies that investigated the relationship between corporate governance and agreement levels with IFRS disclosure in emerging countries were carried out by Al-Akra et al. (2010) in Jordan; Alanezi and Albuloushi (2011) in Kuwait; and Ba-Abbad and Wan-Hussin (2011) in Oman. Yet, not many studies have tested simultaneously the three sets of CG mechanisms - characteristics board, characteristics audit committee, and structures of share's ownership.

Based on the studies above, the problem to be answered in this study is how the effect of the CG mechanism and compliance of IFRS disclosure on the quality of accounting information is revealed. Thus, this study was conducted to obtain empirical evidence about it. This research needs to be done because the previous research on the impact of IFRS implementation on accounting information is mixed (some have positive, negative, and no impact). With the answer to the research question above, the findings of this study are expected to explain why the findings of the previous research are not conclusive. Therefore, this result contributes to enrich the literature on the effectiveness of the CG mechanism of a company and enables regulators to tighten regulations regarding compliance with applicable accounting standards.

The research is conducted for Indonesian companies. Indonesia is one of the developing countries in which the companies started to implement IFRS gradually in 2008 and has fully adopted it since 2012. One common characteristic of business practices in a developing country is the lower level of law enforcement. Therefore, this research seeks empirical evidence about the impact of IFRS compliance 
along with governance compliance on the accounting information quality, which is accounting information value relevance.

The next section of this paper is to be organized as follows. The second part reviews the theory and the previous research to formulate the research hypothesis. The third part describes the research method and the fourth part details the data analysis and statistical test results. The final section presents the research findings and limitations of the study, including the implications and opportunities for further research.

\section{LITERATURE REVIEW AND HYPOTHESES DEVELOPMENT}

\subsection{Literature review}

CG instruments both openly and ultimately influence the quality of accounting information (Krismiaji et al., 2016). The important role of outside commissioners in the governance practice results in the implementation of most CG principles so that they can endorse the existence of a bulk of independent commissioners (Juhmani, 2017). Improving the quality of financial reporting practices is recognized as one of the main benefits for which the company establishes an audit committee (Blue Ribbon Committee, 1999; Ramsay, 2001). Consequently, various countries reform their CG to strengthen the audit committee's role in overseeing the preparation of financial reports (Smith, 2003).

Sabia and Goodfellow (2003) argue that one of the most critical audit committee's jobs is recognizing the existence of the interdependence among the audit committee, manager, and external auditors. An audit committee will not be effective if the committee does not possess the appropriate elements, namely competent and independent members. Ownership structure also determines the level of monitoring and level of disclosure, so that in a company whose ownership is spread, managers can provide additional information to show that management has acted under the principal's best interests, while highly concentrated ownership tends to have lower disclosure levels (Haniffa and Cooke, 2002). Several previous studies have examined the association between CG process and disclosures. Samaha et al. (2012) found that in Egypt, the governance disclosure level was lower in the companies that possessed a managerial positions duality and the higher ownership concentration.

There are many ways to develop accounting as a theory and as a practical application in the context of globalization. These motivated the researchers to be interested in the field of IFRS adoption in various countries. Verriest et al. (2013) investigated the relationship of CG strength and the choice to adopt IFRS of European public companies in 2005. The results showed that the companies that had strong governance disclose more information, more adhere to and use IAS 39. Other studies show that managers do discretion in complying with disclosure guidelines (Street and Gray, 2002; Owusu-Ansah and Yeoh, 2005). The low obedience causes disclosure to be not optimal, especially if the management has incentives to avoid compliance (Ball et al., 2003), and when the implementation of the rules and CG is weak (Nelson et al., 2010).

\subsection{Hypotheses development}

Based on the previous research and agency theory, Krismiaji and Surifah (2019) find that five aspects of the CG mechanism namely board size, board independence, audit committee size, audit committee independence, and managerial ownership had a positive effect on the compliance levels of IFRS mandatory disclosures. Therefore, the five aspects of the corporate governance mechanism and 
compliance levels of IFRS mandatory disclosures will be further investigated for their influence on the quality of accounting information.

\subsubsection{Compliance levels of IFRS mandatory disclosures and accounting information value relevance}

Accounting information is expected to provide information that can help investors and other users of financial statements in making economic decisions appropriately. The framework for the preparation and presentation of financial statements which is published by the International Accounting Standards Board (IASB) stipulates that the purpose of financial reporting is to produce financial information about reporting entities that are beneficial to investors, potential investors, lenders, and other creditors in decision making (IASB, 2018). To be useful, financial information must have relevant quality and faithful representation (IASB, 2018). Therefore, all economic events that affect the company's current and future financial position must be reflected in the financial statements.

Kothari (2005) suggests that market participants seek high-quality accounting information to overcome information asymmetry between managers and external investors. Francis et al. (2004) identify seven attributes of quality accounting information, namely accrual quality, persistence, value relevance, timeliness, predictability, smoothing, and conservatism. This finding is supported by Barth et al. (2008), which claim that high-quality accounting information results in little earnings management, more timely loss recognition, and more relevant earning and book value. Although relevant is not the only quality attribute of accounting information, it is one of the most important quality attributes.

Tsalavoutas and Dionysia (2014) find that the level of disclosure must have value relevance, not only relative value relevance (R2) but also the valuation coefficients of companies with high compliance which were significantly higher than those with low compliance. Similar findings are also reported by Alkali and Lode (2015). Hassan, Percy, and Steward (2006); Umoren and Enang (2015); Alfraih and Alanezi (2015) who have found evidence that the compliance levels of IFRS mandatory disclosures affect the value relevance of earnings and book value.

Based on the assumption that investors increasingly need information that has a high-value relevance in the financial statements so that they can determine the value of the company more accurately, the researchers predict that the value relevance of information increases if the disclosure level increases. Thus, the researchers predict that the level of disclosure for companies listed on the Indonesian Stock Exchange (IDX) is related to the higher value relevance of the earnings and book value. Therefore, the researchers formulate the hypothesis as follows:

\section{$\mathbf{H}_{1}$ : The compliance levels of IFRS mandatory disclosures positively affects the accounting information value relevance.}

\subsubsection{Boards characteristics and accounting information value relevance}

The board characteristics used in this research include Board size and Board independence. Board independence is commonly seen as the main characteristic that must be owned. Agency theory assumes that multiple roles (the Commissioner concurrently the CEO) reduce the ability of the commissioner to supervise the CEO and thus affects the independence of the board (Haniffa and Cooke, 2002). If the role of $\mathrm{CEO}$ and commissioner is combined, it causes agency problems because an individual has the capacity and power to deviously mislead information to users (Yermack, 1996; Ho and Wong, 2001). According to Chen and Jaggi (2000) independent commissioners may advise company directors about strategic 
decisions, such as decision to release financial information, whereas commissioners who have a more independent commissioners use more control authority and more supervising of management decisions. Some previous studies document the positive relationship between Board independence and actions to satisfy the interests of shareholders. Besides, the percentage of outside Board members is usually used to measure the independence of the Board.

The previous research has consistently shown that an independent Board is positively associated with the effectiveness of monitoring the preparation of financial statements. Beekes et al., (2004) find that the companies that have a relatively high proportion of outsiders are more conservative. Kiel and Nicholson (2003) who have examined the relationship between Board demographics and company performance in Australian companies find a positive relationship between the percentage of internal Board members and company value. Agrawal and Knoeber (1996), find a negative association between external Board and company performance. Empirically Klein (2002) find a negative association between the independent board and abnormal accruals, while Davidson et al., (2005) show that the majority of non-executive boards is negatively associated with earnings management.

Other research on the influence of board independence on the value relevance of accounting information tends to be inconclusive. Holtz and Neto (2010) report that earnings informativeness are positively affected by the independence of the board, while Tshipa, Brummer, Wolmarans, and Toi (2018); Mungly, Babajee, Maraye, Seetah, and Ramdhany (2016); Siekkinen (2016); Cupboards (2017); Nugroho and Hatane (2017) find that board independence has a positive effect on the value relevance of accounting information. Furthermore, Habib and Azim (2008); Alfraih, Alanezi, and Alanzi (2015); Ibanichuka and Briggs (2018); Khidmat, Wang, and Awan (2018); Pratiwi, Sutrisno, and Rahman (2019) find that corporate governance has a positive impact on the value relevance of accounting information. Yet, some researchers show different results.

Linda (2018) find that board independence has a positive effect on book value but negatively affect earnings. Whelan (2007) find that corporate governance practices increase the value relevance of earnings but reduce the value relevance of equity book values. Fiador (2013) and Saseela (2018) find that board independence as measured by the percentage of non-executive boards negatively affects the value relevance of stock market valuations, whereas Bahri, Behnamoon, and Hoseinzadeh (2013) find that board independence does not affect accounting value relevance. Based on the description above, the researchers formulate the hypothesis as follows.

\section{$\mathrm{H}_{2}$ : The Board's independence positively affects the accounting information value relevance.}

Board size is determined by total members. The board is large if there are many members, and vice versa. The researchers distinguish between the effectiveness of large and small boards in overcoming earnings management practices and minimizing agency costs. Some researchers consider that large-sized boards are effective because they have a greater ability to protect the interests of shareholders. This happens because the large size means greater ability, experience, and more diverse expertise, to improve the alignment of governance boards. The large capacity of the Board helps strengthen the links between the company and its environment, provides direction and advice on the choice of company strategies and plays an important role in the creation of corporate identity (Pearce and Zahra, 1989; Rahman and Ali, 2006). On the other hand, many researchers criticize this view and assume that the small size of the Board is more effective than the large-sized Board (Alkdai and Hanefah, 2012). They assume that large-sized boards make coordination, communication, and the decision-making process difficult.

According to Forbes and Milliken (1999), Board size influences effectiveness, because (1) Large boards have more unused knowledge and skills, and (2) Large boards tend to have a difficulty in 
coordinating the contributions of each member, so that the company has also a difficulty in utilizing the Board members' knowledge and skills effectively. Also, a large Board complicates personal relationships, relationships of trust, maintaining cohesiveness, and adherence to norms.

Some previous studies have found that board size has a negative effect on the value relevance of accounting information. Abdellatif (2009) who analyzes the relationship between Board size and composition concludes that Board size negatively affects company performance and positively affects firm value. Siekkinen (2016) reports that after the adoption of IFRS, companies that have a larger board size have lower information quality. Fiador (2013); Alfraih, Alanezi, and Alanzi (2015); Mungly, Babajee, Maraye, Seetah, and Ramdhany (2016) find that companies with small board sizes increase the value relevance of earnings and book value. Some studies also show mixed results. Linda (2018) find that board size has a positive effect on the value relevance earnings but negatively affects value relevance book value. However, some studies have the opposite evidence. Holtz and Neto (2010); Cupboards (2017); Adaa and Hanefah (2018) find that board size is positively associated with the value relevance of accounting information, while Bahri, Behnamoon, and Hoseinzadeh (2013) find that board size does not affect accounting value relevance. Based on the description above, the researchers formulate the hypothesis as follows.

\section{$\mathrm{H}_{3}$ : The Board size positively affects the accounting information value relevance.}

\subsubsection{Audit committee characteristics and accounting information value relevance}

Klein (2002) states that the independence of audit committees influences the effectiveness of audit committees in monitoring financial reporting, because of the influence of the independence on the ability of commissioners to effectively monitor corporate financial reporting. Felo et al. (2003) and Abbott et al. (2004) argue that the independence of the audit committee is claimed to be a mandatory requirement for the committee to be able to carry out its responsibilities objectively. Bradbury et al. (2006) find a relationship between the independence of audit committees and high financial reporting quality.

Ayadi and Boujelbene (2015); Ibanichuka and Briggs (2018) reveal that the independence of the audit committee does not significantly influence the value relevance of accounting information. Raymond, Lau, and $\mathrm{Ng}$ (2011); Cupboards (2017); Saseela (2018) show that the independence of the audit committee does not increase the value of the company despite having a high level of compliance. Fakhari et al. (2017) explain that the independence of audit committees is positively associated with the information environment. Atika et al. (2017) assert that the effectiveness of audit committees strengthens the value relevance of estimating the fair value of assets in levels 2 and 3. Mbobo and Umerun (2016); Alqatamin (2018) state that the independence of the audit committee has a significant positive association with company performance. Based on the description above, the researchers formulate the hypothesis as follows.

\section{$\mathrm{H}_{4}$. The independence of the audit committee positively affects the value relevance of accounting information.}

The size of the audit committee is assumed to give a better internal CG. According to Menon and Williams (1994) a less than three member audit committee is likely to be ineffective. Large audit committee is assumed to be more valuable because they have more various members with varying expertise. Such expertise will enable the audit committee to carry out diverse work in relation with supervising financial reports preparations (Anderson et al., 2004). Accordingly, Felo et al. (2003) discover 
the positive effect of large audit on the excellence of financial reporting. Moreover, the size of the audit committee is inversely related to the company's cost of debt, which is an attribute for the influence of the size of the audit committee on disclosure transparency (Anderson et al., 2004). Habib and Azim (2008) find that a strong governance structure increases the value relevance of accounting information. Amin et al (2018) show that the size of the audit committee has a positive effect on earnings quality. Alqatamin (2018) clarifies that the size of the audit committee has a significant positive relationship to company performance.

A research that is more focused on the relevant value of accounting information is carried out by Almari (2017) and Saseela (2018) who report that audit committee size has a positive effect on the value relevance of accounting information, while Mbobo and Umerun (2016) explain that audit committee size has a significant effect on the value relevance of accounting information. Yet, some researchers like Ibanichuka and Briggs (2018) find the opposite evidence. They proclaim that the size of the audit committee has a negative impact on the value relevance of the accounting information. Based on this condition, the researchers formulate the hypothesis as follows:

\section{$\mathrm{H}_{5}$. The audit committee size positively affects the value relevance of accounting information.}

\subsubsection{Managerial ownership and the value relevance of accounting information}

Managers who own company shares are motivated to increase the value of the company, increase not only the welfare of shareholders, but also their welfare (Juhmani, 2017). Managerial ownership is useful to reduce opportunistic actions taken by managers towards the company. Therefore, all activities carried out by managers are expected to increase the value of the company. However, high managerial ownership can also create a defense for managers to provide personal benefits (Morck, Shleifer, and Vishny, 1988).

At the ownership level above 5\%, a manager can act according to his interest because he feels that he has a sufficient defense. This situation will certainly have an impact on the accounting information produced. Correspondingly, the level and quality of disclosed information will enhance since managers who have large numbers of company shares will conform with standard reporting rules and release more information. Usman et al. (2017) state that the stronger corporate governance the higher the value relevance of comprehensive earnings. Ruan et al. (2011) clarify that managerial ownership influences the capital structure thereby increasing the value of the company. Warfield, Wild, and Wild (1995) and Linda (2018) assert that managerial ownership has a positive effect on the value relevance of accounting information both for earnings and book value, while Ayadi and Boujelbene (2015) report that concentrated ownership has a positive effect on the value relevance of earnings. Based on this condition, the researchers formulate the hypothesis as follows:

\section{$\mathrm{H}_{6}$. Managerial ownership positively affects the value relevance of accounting information}

\section{METHODOLOGY}

\subsection{Sample selection}

Indonesian companies have been required to prepare financial reports following IFRS starting in the fiscal year 2012. Therefore, the research years chosen is five years after 2012, i.e. from 2013 to 2017. Samples are selected based on the following criteria: (1) the companies have complete data, (2) the companies have begun to adopt IFRS starting in 2012. The data were obtained from various sources, 
which are the Indonesian Stock Exchange (IDX) database, ICMD databases, and company annual reports. In accordance with the previous literature, this research uses ordinary least-squares (OLS) regression to examine the relationship among the levels of corporate governance, compliance level of IFRS mandatory disclosures and value relevance of accounting information and control variables.

\subsection{Variables' definition and measurement}

The dependent variable in this study is the quality of the accounting information that is measured by value relevance (VR). Ohlson's Price Model (1995) offers a model that links market value with earnings and book value. In this model, current earnings function as a proxy of abnormal return, while book value as a proxy for the cash value of the expected normal future earnings. The Ohlson model expresses the company's market value (company stock price) as a linear function of earnings, book value, and relevant value information. This model has several requirements and produces benchmarks that conceptualize how to link market values with accounting data and other relevant information. This model is specified as follows:

$$
P_{i t}=\alpha_{i t}+\beta_{1} E S_{i t}+\beta_{2} \text { BVS }_{i t}+\varepsilon_{i t}
$$

where:

$$
\begin{array}{ll}
\mathrm{P}_{\mathrm{it}} & =\text { share price for firm } \mathrm{i} \text { in the period of } \mathrm{t} \text { three months after the end of period } \mathrm{t} \\
\mathrm{EPS}_{\text {it }} & =\text { earnings per share for firm } \mathrm{i} \text { in the period of } \mathrm{t} \\
\mathrm{BVS}_{\mathrm{it}} & =\text { book value per share for firm } \mathrm{i} \text { in the period of } \mathrm{t} \\
\varepsilon_{\mathrm{it}} & =\text { error term }
\end{array}
$$

The statistical relationship between stock price and earnings and book value is used as the main metric to measure the value relevance of accounting numbers. If accounting variables are relevant to investors, then there is a relationship between stock prices and earnings and book value. Besides, the earnings coefficient and book value will be statistically significant. This association is measured using the $\mathrm{R}^{2}$ regression model (1).

The independent variable is a corporate governance and the level of compliance with IFRS disclosures. Corporate governance consists of board independence (BIND), board size (BSIZE), independence of the audit committee (ACIND), audit committee size (ACSIZE), and management ownership (MAN) that reflect CG characteristics. BIND is measured by the percentage of non-executive commissioners on the board and BSIZE is measured by the number of board members. ACIND is measured by the percentage of non-executive commissioners in the audit committee and ACSIZE is measured by the number of audit committee members. MAN is measured based on the proportion of shares held by managers (directors and commissioners).

The level of IFRS disclosure compliance is measured using the index (disclosure compliance index/DIND). The previous research on disclosures constructed different disclosure indices. Some researchers construct their indices, others use indexes developed by other researchers. As with previous research on IFRS compliance (Glaum and Street, 2003; Al-Shammari et al., 2008; Hodgdon et al., 2009), this study also uses a self-constructed index consisting of items that must be disclosed. To measure compliance with IFRS disclosure obligations, this study uses a dichotomy approach. The disclosure score is calculated for each company and is used as the dependent variable in the regression model. The total score of IFRS disclosure for a company is the same as the number of items disclosed in the annual report (if it is not in the annual report, it is treated as non-disclosure). The disclosure index is made to measure the relative level of IFRS disclosure after calculating the total disclosure score for each company. An index is the ratio of the actual score obtained by a company divided by the possible maximum score. To 
examine the relationship between the dependent variable and the independent variable, the researcher included control variables that might be related. This study uses three control variables, which are, profitability (PROF) which is measured by dividing net income by total equity, industry type (IND) which is a dummy variable and worth 1 for financial companies and 0 for non-financial, and leverage (LEV) which measured by dividing the number of liabilities by the number of assets.

\subsection{Model specification}

This study uses a multivariate model to test the hypothesis. To determine the effect of three CG mechanism groups (board characteristics, audit committee characteristics, and ownership structure) and the level of compliance of IFRS disclosure (DIND) to the relevant value of accounting information, the model (2) which is an extension of the model (1) is used as follows:

$$
\begin{aligned}
& P_{i t}=\alpha+\beta_{1} \text { EPS }_{i t}+\beta_{2} \text { BVS }_{\text {it }}+\beta_{3} \text { DIND }_{\text {it }}+\beta_{4} \text { BIND }_{\text {it }}+\beta_{5} \text { BSIZE }_{i t}+\beta_{6} \mathrm{ACIN}_{\text {it }}+ \\
& \beta_{7} \mathrm{ACSIZE}_{\mathrm{it}}+\beta_{8} \mathrm{MAN}_{\mathrm{it}}+\beta_{9} \mathrm{DIND}_{\mathrm{it}} * \mathrm{EPS}_{\mathrm{it}}+\beta_{10} \mathrm{DIND}_{\mathrm{it}} * \mathrm{BVS}_{\mathrm{it}}+ \\
& \beta_{11} \text { BIND }_{\text {it }}{ }^{*} \mathrm{EPS}_{\text {it }}+\mathrm{B}_{12} \mathrm{BIND}_{\mathrm{it}} * \mathrm{BVS}_{\mathrm{it}}+\mathrm{B}_{13} \mathrm{BSIZE}_{\mathrm{it}}{ }^{*} \mathrm{EPS}_{\mathrm{it}}+\mathrm{B}_{14} \mathrm{BSIZE}_{\mathrm{it}} * \mathrm{BVS}_{\mathrm{it}}+\beta_{15} \mathrm{ACIN}_{\mathrm{it}}{ }^{*} \mathrm{EPS}_{\text {it }} \\
& +\mathrm{B}_{16} \mathrm{ACIN}_{\mathrm{it}} * \mathrm{BVS}_{\mathrm{it}}+\mathrm{B}_{17} \mathrm{ACSIZE}_{\mathrm{it}} * \mathrm{EPS}_{\mathrm{it}}+\mathrm{B}_{8} \mathrm{ACSIZE}_{\mathrm{it}} * \mathrm{BVS}_{\mathrm{it}}+\beta_{19} \mathrm{MAN}_{\mathrm{it}} * \mathrm{EPS}_{\mathrm{it}}+ \\
& \beta_{20} \mathrm{MAN}_{\mathrm{it}} * \mathrm{BVS}_{\mathrm{it}}+\mathrm{B}_{21} \mathrm{PROF}_{\mathrm{it}}+\beta_{22} \mathrm{IND}_{\text {it }}+\beta_{23} \mathrm{LEV}_{\mathrm{it}}+\varepsilon
\end{aligned}
$$

DINDit is a disclosure index for a company $i$ in the year $t$, BINDit is an independent board for a company $i$ in the year $t$, BSIZEit is a board size for the company $i$ in the year $t$, ACINDit is an independent audit committee for a company $i$ in the year $t$, ACSIZEit is a measure of the audit committee for a company $i$ in the year t, MANit is ownership managerial for a company $i$ in the year t, PROFit is the profitability for a company $i$ in the year $t$, INDit is the type of industry for a company $i$ in the year $t$, LEVit is the leverage for a company $i$ in the year $t$, and $e$ is an error term. To test all hypotheses (IFRS disclosure compliance level, board characteristics, audit committee characteristics, and ownership structure) we use model 2, whereas to test the consistency of each interest variable individually, we use model 3 to test the level of compliance with IFRS disclosure (H1), Model 4 to test board independence (H2) and board's size (H3), Model 5 to test audit committee independence (H4) and audit committee size (H5), and Model 6 to test ownership structure are as follows:

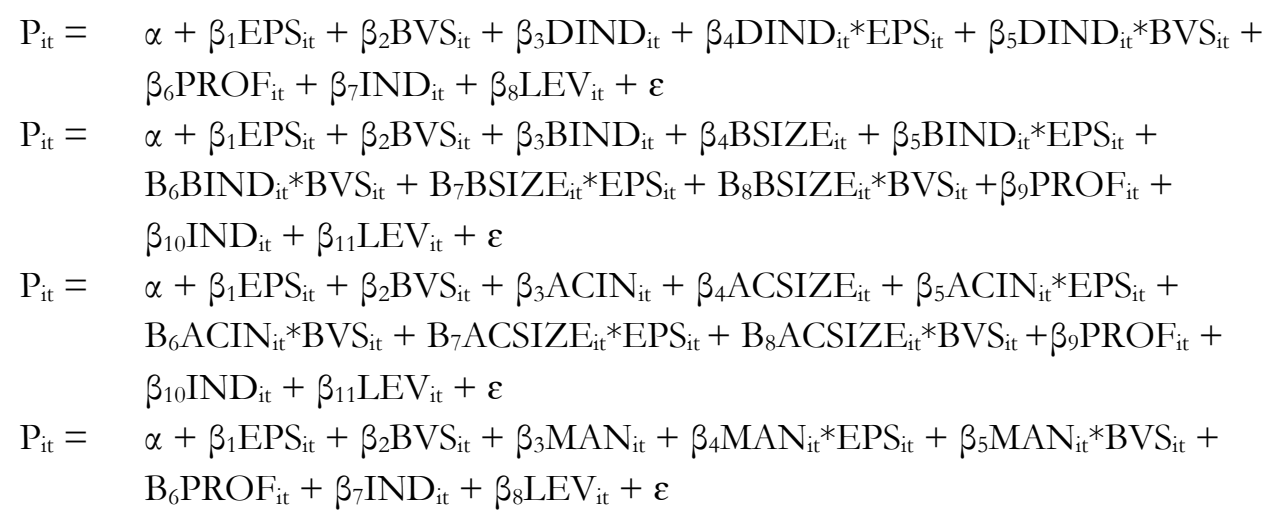




\section{EMPIRICAL RESULTS AND DISCUSSION}

\subsection{Sample}

Based on the sampling method, this research uses. This research uses a sample of 490 companies that were studied for five years, i.e. in 2013 and in 2007 so that the number of observations used in this study amounted to 2.450 firm-years. The sample data per industry can be seen in table 1 . All industries that have complete data are used as samples.

Table 1

Firm data per industry

\begin{tabular}{|c|l|c|}
\hline No. & \multicolumn{1}{|c|}{ Industry } & Number \\
\hline 1 & Agriculture & 20 \\
\hline 2 & Basic Industry and Chemicals & 39 \\
\hline 3 & Consumer Goods Industry & 63 \\
\hline 4 & Infrastructure, Utilities, and Transportation & 40 \\
\hline 5 & Mining & 36 \\
\hline 6 & Miscellaneous Industry & 55 \\
\hline 7 & The property, Real Estate, and Building Construction & 50 \\
\hline 8 & Finance & 79 \\
\hline 9 & Trade, Services \& Investment Total & 108 \\
\hline & & 490 \\
\hline
\end{tabular}

\subsection{Univariate analysis}

Table 2 shows the descriptive statistics of the research variables. Table 2 reports that the mean (median) stock price per share for the period 2013 to 2017 is 3.199,982 (615.00) with a standard deviation of 12.375,850. Earnings per share (EPS) has a mean (median) 138,330 (29.00) with a standard deviation of 1.199,791 and a book value per share (BVS) has a mean (median) of 1.279,120 (425.00) with a standard deviation of 3.339,685.

Table 2

Descriptive statistic

\begin{tabular}{|c|c|c|c|c|c|}
\hline & Mean & Median & Maximum & Minimum & Std. Dev. \\
\hline P & $3.199,982$ & 615,000 & $19.9500,000$ & 50,000 & $12.375,850$ \\
\hline EPS & 138,330 & 29,000 & 8554,000 & $-17.350,000$ & $1.199,791$ \\
\hline BVS & $1.279,120$ & 425,000 & $32.609,000$ & $-12.185,000$ & $3.339,685$ \\
\hline DIND & 0,710 & 0,720 & 0,970 & 0,390 & 0,084 \\
\hline BIND & 0,396 & 0,333 & 1,500 & 0,000 & 0,171 \\
\hline BSIZE & 4,004 & 3,000 & 22,000 & 2,000 & 1,999 \\
\hline ACIND & 0,136 & 0,000 & 0,667 & 0,000 & 0,181 \\
\hline ACSIZE & 2,878 & 3,000 & 8,000 & 0,000 & 1,111 \\
\hline MAN & 0,021 & 0,000 & 0,742 & 0,000 & 0,077 \\
\hline PROF & 15,502 & 10,070 & 423,210 & $-147,200$ & 53,752 \\
\hline IND & 0,143 & 0,000 & 1,000 & 0,000 & 0,350 \\
\hline LEV & 0,590 & 0,535 & 12,000 & 0,000 & 0,801 \\
\hline
\end{tabular}


From Table 2 it can also be seen that the DIND mean shows a value of 0.710 with a standard deviation of 0.084 . Because of this variable to measure disclosure compliance, the higher the value of the DIND the more compliant the company is. BIND and BSIZE have mean values of 0.396 and 4.004 with standard deviations of 0.171 and 1.999 respectively. ACIND and ACSIZE have mean values of 0.136 and 2.878 with standard deviations of 0.181 and 1.111 respectively, while MAN has mean values of 0.021 with standard deviations of 0.077 .

\subsection{Bivariate analysis}

This study uses OLS in testing hypotheses. Before conducting a regression analysis, the classic assumption test is done first. The classic assumption test results show that data are normally distributed and there are no multicollinearity, autocorrelation, heteroscedasticity problems, and no outliers' data. Then the correlation test between variables is carried out. The results of the correlation test between variables are presented in Table 3. Table 3 shows that the correlation between independent variables is relatively small with the highest value of 0.301, namely the correlation between ACSIZE and BSIZE. This means there is no multicollinearity. Table 3 also shows the results of the Pearson correlation between research variables and between the independent variables and the dependent variable. The results show that EPS and BVS are positively and significantly correlated. This is an initial indication to prove the hypothesis. Testing the complete hypothesis is done by multiple regression analysis.

Table 3

Analysis bivariate

\begin{tabular}{|c|c|c|c|c|c|c|c|c|}
\hline & $\mathrm{P}$ & EPS & BVS & DIND & BIND & BSIZE & ACIND & ACSIZE \\
\hline EPS & $.721^{* *}$ & & & & & & & \\
\hline BVS & $.532^{* *}$ & $.271^{* *}$ & & & & & & \\
\hline DIND &,- 005 &,- 004 &,- 012 & & & & & \\
\hline BIND & $-.058^{* *}$ & $-.062^{* *}$ & $-.040^{*}$ & $-.101^{* *}$ & & & & \\
\hline BSIZE & $.060^{* *}$ & $.049^{*}$ & $.147^{* *}$ &,- 003 & $.041^{*}$ & & & \\
\hline ACIND &,- 027 & $-.041^{*}$ &,- 011 &,- 033 & $.266^{* *}$ & $.047^{*}$ & & \\
\hline ACSIZE & $-.047^{*}$ & $-.044^{*}$ &, 026 &,- 037 & $.196^{* *}$ & $.301^{* *}$ & $.129^{* *}$ & \\
\hline MAN &,- 021 &,- 020 &,- 022 &,- 012 &, 003 & $.041^{*}$ & $.053^{* *}$ &,- 012 \\
\hline
\end{tabular}

**. Correlation is significant at the 0.01 level (2-tailed).

*. Correlation is significant at the 0.05 level (2-tailed).

\subsection{Multivariate analysis}

Table 4 shows the results of regression analysis to test the hypothesis. The F and adjusted R2 values of the four regression models indicate that the four multiple regression models are very statistically significant. However, there are several differences in the explanatory power of various types of independent variables as indicated by the adjusted R2. The number of variations described in the disclosure index was 81,7 percent for model 2; 29,3 percent model 3; 51,8 percent for model 4; 79,6 percent for model 5 ; and 24,1 percent for model 6 .

To test hypothesis 1 , Model 2 is used. The variables tested are the interaction variables between the disclosure index (DIND) and EPS and BVS, namely DIND*EPS and DIND*BVS. Table 4 in the Model 2 column shows that the DIND*EPS variable coefficient value is 82.620 and is significant at level $1 \%$ while the DIND*BVS variable coefficient value is 7.292 and is significant at $1 \%$ level. These results 
indicate that the compliance level of IFRS mandatory disclosure positively influences the value relevance of accounting information for both EPS and BVS. Thus it can be concluded that hypothesis 1 which states that the compliance level of mandatory disclosure of IFRS has a positive effect on the value relevance is proven and is supported by empirical data. The results of this study are partly consistent with previous research conducted by Tsalavoutas and Dionysia (2014); Alkali and Lode (2015); Hassan, Percy, and Steward (2006); Umoren and Enang (2015); and Alfraih and Alanezi (2015) who found a strong relationship between levels of IFRS compliance with the value relevance of earnings and book value.

Hypothesis 2 and hypothesis 3 are tested using Model 2. The tested variables are the interaction between board independence (BIND) and EPS and BVS, namely BIND*EPS and BIND*BVS, and interactions between board size (BSIZE) and EPS and BVS, BSIZE*EPS and BSIZE*BVS. Table 4 in the Model 2 column shows that the BIND*EPS variable coefficient value is $-12,831$ and is significant at the level of $1 \%$, while the BIND*BVS variable coefficient value is 0,433 and is significant at the $1 \%$ level. These results indicate that board independence has a positive effect on the value of relevant accounting information for BVS, while for EPS it has a negative effect. Thus it can be concluded that hypothesis 2 which states that the proportion of independent Board members has a positive effect on the relevant value of accounting information after IFRS implementation is partly proven, for the relevant value of BVS, while for the relevant value EPS it is proven otherwise. These results confirm the results of research conducted by Linda (2018) who has found that board independence has a positive effect on the relevant value of book values but has a negative effect on earnings. These results also confirm part of the results of research conducted by Tshipa, Brummer, Wolmarans, and Toi (2015); Mungly, Babajee, Maraye, Seetah, and Ramdhany (2016); Siekkinen (2016); Cupboards (2017); Nugroho and Hatane (2017) who have found that board independence had a positive effect on the relevant value of accounting information.

Model 2 shows that the BSIZE*EPS variable coefficient is 0.855 and is significant at the $1 \%$ level, while the BSIZE*BVS variable coefficient value is 0.122 and is significant at the $1 \%$ level. These results indicate that board size has a positive effect on the value of relevant accounting information for BVS and EPS. Thus it can be concluded that hypothesis 3 which states that board size positively affects the value relevance of accounting information after IFRS implementation is proven both for EPS and BVS. These results confirm previous research findings conducted by Holtz and Neto (2010); Cupboards (2017); Adaa and Hanefah (2018) who find that board size is positively related to the value relevance of accounting information. These results also confirm some of the findings of research conducted by Linda (2018) who find that board size has a positive effect on the value relevance of earnings but negatively affects the value relevance of book value.

Hypotheses 4 and 5 were tested using Model 2. The tested variables were the interaction between the independence of the audit committee (ACBIND) with EPS and BVS, namely ACIND*EPS and ACIND*BVS, and the interaction between the size of the audit committee (ACSIZE) and EPS and BVS, namely ACSIZE*EPS and ACSIZE*BVS. Table 4 in the Model 2 column shows that the coefficient value of the ACIND*EPS variable is -36.674 and is significant at level $1 \%$, while the coefficient value of the ACIND*BVS variable is 5.226 and is significant at the level of $1 \%$. These results indicate that the independence of the audit committee has a positive effect on the value of relevant accounting information for BVS, while for EPS, it has a negative effect. Thus, it can be concluded that hypothesis 4 which states that the independence of the audit committee is positively related to the value relevance of accounting information after IFRS implementation is proven partly, namely for the relevant value of BVS, while for the relevant value EPS, it is proven otherwise. These results confirm previous research findings conducted by Ayadi and Boujelbène (2015); Ibanichuka and Briggs (2018) who report that the existence of audit committees negatively affects earnings value relevance, and the research conducted by Mbobo and 
Umerun (2016) show that the independence of audit committees has a significant positive effect on the value relevance of accounting information.

Tabel 4

Regression analysis

\begin{tabular}{|c|c|c|c|c|c|}
\hline Variable & $\begin{array}{c}\text { Model 2 } \\
\text { Coefficient } \\
\text { (t-Statistic) }\end{array}$ & $\begin{array}{c}\text { Model } 3 \\
\text { Coefficient } \\
\text { (t-Statistic)) }\end{array}$ & $\begin{array}{c}\text { Model } 4 \\
\text { Coefficient } \\
\text { (t-Statistic) }\end{array}$ & $\begin{array}{c}\text { Model 5 } \\
\text { Coefficient } \\
\text { (t-Statistic) }\end{array}$ & $\begin{array}{c}\text { Model } 6 \\
\text { Coefficient } \\
\text { (t-Statistic) }\end{array}$ \\
\hline Intercept & $\begin{array}{l}578,243 \text { *** } \\
(25,132)\end{array}$ & $\begin{array}{c}883,141 \text { ** } \\
(2,425)\end{array}$ & $\begin{array}{c}1.341,962 * * * \\
(7,125)\end{array}$ & $\begin{array}{l}633,571 \text { *** } \\
(2,577)\end{array}$ & $\begin{array}{c}1.167,675 \text { *** } \\
(4,690)\end{array}$ \\
\hline EPS & $\begin{array}{l}-57,370 \text { *** } \\
(-24,138)\end{array}$ & $\begin{array}{l}21,464 \text { *** } \\
(5,723)\end{array}$ & $\begin{array}{l}15,175 \text { *** } \\
(12,257)\end{array}$ & $\begin{array}{l}2,046 \text { *** } \\
(4,252)\end{array}$ & $\begin{array}{r}0,411 \\
(0,612)\end{array}$ \\
\hline BVS & $\begin{array}{c}6,352 \\
(32,775)\end{array}$ & $\begin{array}{r}2,646 \text { *** } \\
(119,755)\end{array}$ & $\begin{array}{c}-0,435 \text { *** } \\
(-49,214)\end{array}$ & $\begin{array}{r}0,456 \\
(0,837)\end{array}$ & $\begin{array}{l}1,707 \text { *** } \\
(8,954)\end{array}$ \\
\hline DIND & $\begin{array}{l}-722,440 \text { *** } \\
(-43,106)\end{array}$ & $\begin{array}{l}64,025 * * * \\
(0,069)\end{array}$ & & & \\
\hline DIND*EPS & $\begin{array}{c}82,620 \\
(29,274) \\
\end{array}$ & $\begin{array}{l}30,902 * * \\
(4,633)\end{array}$ & & & \\
\hline DIND*BVS & $\begin{array}{c}7,292 \text { *** } \\
(25,831)\end{array}$ & $\begin{array}{l}1,036 \text { *** } \\
(4,409)\end{array}$ & & & \\
\hline BIND & $\begin{array}{c}1.949,907 \text { *** } \\
(13,714)\end{array}$ & & $\begin{array}{r}165,173 \\
(0,463)\end{array}$ & & \\
\hline BSIZE & $\begin{array}{c}422,684 \text { *** } \\
(103,077)\end{array}$ & & $\begin{array}{l}796,957 \text { *** } \\
(13,061)\end{array}$ & & \\
\hline BIND*EPS & $\begin{array}{l}-12,831 * * * \\
(-96,840)\end{array}$ & & $\begin{array}{l}-53,402 * * * \\
(-20,131)\end{array}$ & & \\
\hline BIND*BVS & $\begin{array}{c}0,433 \\
(17,819)\end{array}$ & & $\begin{array}{l}7,320 \text { *** } \\
(11,765)\end{array}$ & & \\
\hline BSIZE*EPS & $\begin{array}{c}0,855 \text { *** } \\
(69,750)\end{array}$ & & $\begin{array}{r}4,536 \text { *** } \\
(914,899)\end{array}$ & & \\
\hline BSIZE*BVS & $\begin{array}{c}0,122 \\
(707,367)\end{array}$ & & $\begin{array}{l}0,743 \text { *** } \\
(62,404)\end{array}$ & & \\
\hline ACIND & $\begin{array}{c}-2.939,534 \\
(-24,720)\end{array}$ & & & $\begin{array}{l}-4.577,208 \text { *** } \\
(-135,208)\end{array}$ & \\
\hline ACSIZE & $\begin{array}{l}39,780 * * * \\
(3,942)\end{array}$ & & & $\begin{array}{l}584,637 \text { *** } \\
(44,908)\end{array}$ & \\
\hline ACIND*EPS & $\begin{array}{l}-36,674 \text { *** } \\
(-70,771)\end{array}$ & & & $\begin{array}{r}-31,383 \\
(-27,230)\end{array}$ *** & \\
\hline ACIND*BVS & $\begin{array}{c}5,226 \text { *** } \\
(30,389)\end{array}$ & & & $\begin{array}{c}5,122 \text { *** } \\
(21,045)\end{array}$ & \\
\hline ACSIZE*EPS & $\begin{array}{c}5,200 \text { *** } \\
(38,992)\end{array}$ & & & $\begin{array}{l}5,112 \text { *** } \\
(9,942)\end{array}$ & \\
\hline ACSIZE*BVS & $\begin{array}{c}-0,549 \\
(-47,301) \\
\end{array}$ & & & $\begin{array}{l}-0.472 \text { *** } \\
(-2,818)\end{array}$ & \\
\hline MAN & $\begin{array}{r}1.376,827 \\
(8,281) \\
\end{array}$ & & & & $\begin{array}{c}232,458 \text { *** } \\
(0,390)\end{array}$ \\
\hline MAN*EPS & $\begin{array}{c}-41,442 \\
(-57,736)\end{array}$ & & & & $\begin{array}{r}-7,385 \\
(-0,549) \\
\end{array}$ \\
\hline MAN*BVS & $\begin{array}{l}3,753 \text { *** } \\
(30,977)\end{array}$ & & & & $\begin{array}{r}-2,799 \text { *** } \\
(-114,751)\end{array}$ \\
\hline PROF & $\begin{array}{c}-1,630 * * * \\
(-25,352)\end{array}$ & $\begin{array}{r}-1.304 \\
(-1,258)\end{array}$ & $\begin{array}{l}-1,267 * * * \\
(-4,372)\end{array}$ & $\begin{array}{r}0,202 \\
(0,165)\end{array}$ & $\begin{array}{l}0,005 \text { *** } \\
(-007)\end{array}$ \\
\hline IND & $\begin{array}{l}-847,205 \text { *** } \\
(-53,131)\end{array}$ & $\begin{array}{c}-1.611,769 \text { *** } \\
(-52,733)\end{array}$ & $\begin{array}{c}-1.694,364 * * * \\
(-34,572)\end{array}$ & $\begin{array}{rl}-1.440,227 & * * * \\
(-36,819) & \end{array}$ & $\begin{array}{c}-1.677,830 \text { *** } \\
(-22,596)\end{array}$ \\
\hline LEV & $\begin{array}{c}-64,230 \text { *** } \\
-(19,128) \\
\end{array}$ & $\begin{array}{l}273,182 \text { *** } \\
(4,859)\end{array}$ & $\begin{array}{l}202,211 \text { *** } \\
(3,356)\end{array}$ & $\begin{array}{l}162,058 \text { *** } \\
(2,621)\end{array}$ & $\begin{array}{c}233,588 \text { ** } \\
(4,169)\end{array}$ \\
\hline Adj. $\mathrm{R}^{2}$ & 0,817 & 0,293 & 0,518 & 0,496 & 0,241 \\
\hline F-statistic & 477,338 *** & $128,421 \quad * * *$ & $240,879 * * *$ & $220,194 * * *$ & $98,481 * * *$ \\
\hline
\end{tabular}

$* * *, * *, *$ show that coefficient significant at the level of $0.01,0.05$, dan 0.1 respectively. 
Model 2 also shows that the ACSIZE*EPS variable coefficient is 5.200 and is significant at the $1 \%$ level, while the ACSIZE*BVS variable coefficient value is -0.549 and is significant at $1 \%$ level. These results indicate that the size of the audit committee positively influences the relevant value of accounting information for EPS, whereas for BVS it has a negative effect. Thus it can be concluded that hypothesis 5 which states that the size of the audit committee is positively related to the value relevance of accounting information after IFRS implementation is proven for the relevant value of EPS but is not proven for BVS. The results for EPS confirm that previous research conducted by Almari (2017) and Saseela (2018) who report that the size of the audit committee has a positive effect on the value relevance of accounting information, and Mbobo and Umerun (2016) who find that the audit committee has a significant effect on the value relevance of accounting information. Although the results for BVS do not prove the hypothesis, these results confirm the findings of the study conducted by Ibanichuka and Briggs (2018) who find that the size of the audit committee negatively impacts the relevance of the value of accounting information.

Hypothesis 6 was tested using Model 2. The variables tested were interactions between managerial ownership (MAN) and EPS and BVS, namely MAN*EPS and MAN*BVS. Table 4 in the Model 5 column shows that the coefficients of the MAN*EPS variable is -41.442 and is significant at the level of $1 \%$, while the coefficients of the MAN*BVS variable is 3.753 and is significant at the $1 \%$ level. These results indicate that managerial ownership negatively affects the value relevance of accounting information for both EPS but it positively affects the value relevance of BVS. Thus it can be concluded that hypothesis 6 which states that managerial ownership is positively related to the relevant value of accounting information after IFRS implementation is only proven for BVS relevant values whereas for relevant values EPS is proven to be the opposite or irrelevance. These results confirm previous studies conducted by Warfield, Wild, and Wild (1995) and Linda (2018) who find that managerial ownership positively affects the value relevance of book values.

To test the consistency of the results, the researchers also conducted regression testing for each independent variable using model 3 for disclosure levels, model 4 for boards, model 5 for audit committees, and model 6 for managerial ownership. The results are presented in Table 4 . Table 4 in the Model 3 column shows that the DIND*EPS variable coefficient value is 30.902 and is significant at the $1 \%$ level while the DIND*BVS variable coefficient value is 1.036 and is significant at $1 \%$ level. If these results are compared with the results in Table 4 of the Model 2 column, then this result is y consistent both for DIND*BVS and DIND*EPS.

Table 4 in the Model 4 column shows that the BIND*EPS variable coefficient value is -53.402 and is significant at the $1 \%$ level, while the BIND*BVS variable coefficient value is 7.320 and is significant at the $1 \%$ level. Table 4 in the model 4 column shows that the BSIZE*EPS variable coefficient is 4.536 and is significant at the level of $1 \%$, while the BSIZE*BVS variable coefficient value is 0.743 and is significant at the $1 \%$ level. The test results in model 4 show consistency with the results of testing on model 2 for both BIND and BSIZE.

Table 4 in column 5 shows that the coefficient value of the ACIND*EPS variable is -31.383 and is significant at level $1 \%$, while the coefficient value of the ACIND*BVS variable is 5.122 and is significant at the level of $1 \%$. These results indicate that the independence of the audit committee has a positive effect on the value of relevant accounting information for BVS, while for EPS it has a negative effect. Model 5 also shows that the ACSIZE*EPS variable coefficient is 5.112 and is significant at the $10 \%$ level, while the ACSIZE*BVS variable coefficient value is -0.472 and is significant at $1 \%$ level. These results indicate that the size of the audit committee positively influences the relevant value of accounting information for EPS, whereas for BVS it has a negative effect. The test results in model 5 show consistency with the results of testing on model 2 for both ACIND and ACSIZE. 
Table 4 in model 6 column shows that MAN*EPS variable coefficient is -7.385 and insignificant while MAN*BVS variable coefficient value is -2.799 and significant at level $1 \%$. These results are inconsistent with the results of testing on model 2. The results of model 6 for MAN*EPS indicate that the regression coefficient is not significant, whereas in model 2 the coefficient shows significant results although negative. Moreover, MAN*BVS the results in model 2 show that the coefficient is positive and significant, thus supporting the research hypothesis. The inconsistency results from model 2 and model 6 partly because model 6 does not involve DIND (disclosure index) which is the proxy of IFRS compliance level. Therefore, the model should be tested in the future to get the conclusion about which model is better.

\section{CONCLUSION}

This research examines the relationship between CG, IFRS disclosure compliance and the quality of accounting information. The test results on hypothesis 1 show that the compliance level of IFRS disclosure has value relevance for both EPS and BVS. Thus, hypothesis 1 is proven and supported by empirical data. The results of testing on hypothesis 2 indicate that the independence of the board has a relevant value of BVS, whereas for the relevant value of EPS, it is proven otherwise so that hypothesis 2 is only partially proven. The test results on hypothesis 3 show that the board size has relevant values for both EPS and BVS, so it is concluded that hypothesis 3 is proven and supported by empirical data. The test results on hypothesis 4 indicate that the independence of the audit committee has value relevance for BVS while EPS does not have relevant values, so it is concluded that hypothesis 4 is partly proven. Analysis of hypothesis 5 proves that the size of the audit committee positively affects the value relevance of EPS, while BVS is not proven. Thus, it is concluded that hypothesis 5 is partly proven and partly not supported by empirical research data. The results of testing hypothesis 6 prove that managerial ownership has a negative effect on the relevant value of EPS but has a positive effect on the relevant value of BVS, so hypothesis 6 is only proven for the relevant value of BVS. As explained above, the data in this research were taken in Indonesia, one of the developing countries that has a specific characteristic such as the low enforcement of regulations. Although descriptive statistics show that the mean compliance level is 0.710 with maximum compliance level is 9.70 and the minimum compliance level is 3.90 , the research proves that some hypotheses, which are built on the previous research performed in different countries, are rejected. This indicates that Indonesian companies need to increase their compliance to achieve and enhance better information value relevance.

There are several limitations to this study. First, this study uses data from one country only, that is Indonesia, so it has limitations in generalizing results. A further research can be done using data from more than one country. Secondly, this study uses data taken for two years after IFRS was fully adopted. To enrich the literature on disclosure, a future research needs to consider the data available before full IFRS adoption to obtain a comparative picture of disclosure compliance.

\section{REFERENCES}

Abbott, L.J., Parker, S. \& Peters, G.F. (2004). Audit committee characteristics and restatements, Auditing, A Journal of Practice and Theory, 23 (1), 69-87.

Abdellatif, A.E.M., 2009. Corporate governance mechanisms and asymmetric information, An application on the U. K. Capital Market. Ph.D. thesis, University of Surrey, UK.

Adaa, A.H.M.A, \& M.M. Hanefah. (2018). Board characteristics and Muslim ownership structure on the value relevance of accounting information, evidence from Malaysian shariah-compliant companies. The Journal of Muamalat and Islamic Finance Research, 15 (2), 39-53. 
Agrawal, A. \& Knoeber, C.R. (1996). Firm performance and mechanisms to control agency problems between manager and shareholders, Journal of Financial and Quantitative Analysis, 31 (3), 377-389.

Al-Akra, M., Eddie, I.A. \& Ali, M.J. (2010). The influence of the introduction of accounting disclosure regulation on mandatory disclosure compliance, evidence from Jordan. The British Accounting Review, 42 (3), 170-186.

Alanezi, F.S. \& Albuloushi, S.S. (2011). Does the existence of voluntary audit committees affect IFRS-required disclosure? The Kuwaiti evidence, International Journal of Disclosure and Governance, 8 (2), 148-173.

Alfraih, M.M., F. S. Alanezi, \& K. A. Alanzi. (2015). Do the characteristics of the board of directors affect the value relevance of accounting information? International Journal of Accounting and Finance, 5 (2), 172-187.

Alfraih, M. \& F. Alanezi. (2015). The value relevance of mandatory corporate disclosures, evidence from Kuwait. International Journal of Business and Finance Research, 9 (3), 1-18.

Almari, M.O.S. (2017). The Impact of Corporate Governance Mechanisms on Value Relevance of Accounting Information, Evidence from Jordan. Research Journal of Finance and Accounting, 8(17), 60-66.

Alkali, M.Y \& N.A. Lode. (2015). The Value Relevance of Accounting Disclosures among Nigerian Financial Institutions after the IFRS Adoption. Mediterranean Journal of Social Sciences, 6 (1), 409-418. 6. 10.5901/mjss.2015.v6n1p409.

Alkdai, H. K .H, \& Hanefah, M. M. (2012). Audit committee characteristics and earnings management in Malaysian Shariah-compliant companies. Business and Management Review, 2 (2), 52-61.

Alqatamin, R.M. (2018). Audit Committee Effectiveness and Company Performance, Evidence from Jordan. Accounting and Finance Research, 7 (2), 48-60.

Al-Shammari, B., Brown, P. \& Tarca, A. (2008). An investigation of compliance with international accounting standards by listed companies in the Gulf co-operation council member states, The International Journal of Accounting, 43 (4), 425-447.

Aminul Amin, Niki Lukviarman, Djoko Suhardjanto, \& Erna Setiany. (2018). Audit Committee Characteristics and AuditEarnings Quality, Empirical Evidence of the Company with Concentrated Ownership. Review of Integrative Business and Economics Research, 7 (1), 18-33.

Amiri, G.S. \& Fasihi, S. (2015). The Relationship between Audit Committee Characteristics and the Real and Accrual Earnings Management of Listed Companies in Tehran Stock Exchange, Journal of Iranian Accounting Review, 2 (8), 15-34. DOI, 10.22055/jiar.2015.12416.

Anderson, R., Mansi, S. \& Reeb, D. (2004). Board characteristics, accounting report integrity, and the cost of debt. Journal of Accounting and Economics, 37 (3), 315-342.

Atika Rizki and Aria Farah Mita. (2017). Corporate Governance Mechanisms and Value Relevance of Fair Value Assets under IFRS 1, World Applied Sciences Journal, 35 (11), 2479-2485. DOI, 10.5829/idosi.wasj.2017.2479.2485.

Ayadi, W.M. \& Y. Boujelbène. (2015). Internal governance mechanisms and value relevance of accounting earnings, an empirical study in the French context, International Journal of Managerial and Financial Accounting, 7 (1), 3-25.

Ba-Abbad, K.M. \& Wan-Hussin, W.N. (2011). Internal corporate governance mechanisms and the level of compliance with mandatory IFRSs disclosure requirements, 1st International Conference on Accounting, Business and Economics (ICABEC), Kuala Terengganu, Terengganu, November 1-2.

Bahri, S.J., Behnamoon Y, \& Hoseinzadeh GH. (2013). Board of directors characteristics and value relevance of accounting information in Tehran stock exchange (TSE), Journal Of Accounting Knowledge and Management Auditing, 2 (6), 51-63.

Ball, R., Robin, A. \& Wu, J. (2003). Incentives versus standards, properties of accounting income in four East Asian countries and implications for the acceptance of IAS. Journal of Accounting and Economics, 36 (1-3), 235-270.

Barth, M. W. Landsman, \& M. Lang. (2008). International Accounting Standards and accounting quality. Journal of Accounting Research, 46 (3), 467-498.

Beekes, W., Pope, P., \& Young, S. (2004). The links between earnings timeliness, earnings conservatism, and board composition, Evidence from the U.S. Corporate governance, An international review, 12 (1), 47-59.

Beuselinck, C., P. Joos, \& S.V.D. Meulen. (2007). International earnings comparability. Working paper, Tilburg University. 
Blue Ribbon Committee. (1999). Report and recommendations of the Blue Robin Committee on improving the effectiveness of corporate audit committees. New York Stock Exchange and National Association of Securities Dealers, New York, NY.

Bova, F. \& Pereira, R. (2012). The determinants and consequences of heterogeneous IFRS compliance levels following mandatory IFRS adoption, evidence from a developing country. Journal of International Accounting Research, 11 (1), 83-111.

Bradbury, M., Mak, Y.T., \& Tan, S.M. (2006). Board Characteristics, Audit Committee Characteristics, and Abnormal Accruals. Pacific Accounting Review, 18 (2), 47-68.

Brown, P. (2011). International financial reporting standards, what are the benefits? Accounting and Business Research, 41 (3), 269-285.

Byrne, J. (2002). How to fix corporate governance. Business Week, May 6, available at www. businessweek.com,/print/magazine/content/02_18/b3781701.htm.

Chan, S., Lau, C., \& Ng, A. (2011). Compliance and value relevance of audit committees, Evidence from Hong Kong. Journal of Financial Reporting and Accounting, 9 (1), 74-97. https,//doi.org/10.1108/19852511111139813.

Chen, C.J. \& Jaggi, B. (2000). Association between independent nonexecutive directors, family control and financial disclosures in Hong Kong. Journal of Accounting and Public Policy, 19 (4-5), 285-310.

Covrig, V. M., M. L. DeFond, \& M. Hung. (2007). Home bias, foreign mutual fund holdings, and the voluntary adoption of International Accounting Standards. Journal of Accounting Research 45 (1), 1-70.

Cuijpers, R., \& W. Buijink. (2005). Voluntary adoption of non-local GAAP in the European Union, a study of determinants and consequences. European Accounting Review 14 (3), 487-524.

Davidson, Jenny \& Kent. (2005). Internal governance structures and earnings management, Accounting Finance, 45 (2), 241-267.

Deakin, S. \& Konzelmann, S. (2004). Learning from Enron. Corporate Governance, 12 (2), 134-142.

Dumontier, P., \& B. Raffournier. (1998). Why firms comply voluntarily with IAS, an empirical analysis with Swiss data. Journal of International Financial Management and Accounting, 9 (3), 216-245.

Fakhari, H., \& Y.R. Pitenoei. (2017). The Impact of Audit Committee and Its Characteristics on the Firms' Information Environment. Iranian Journal of Management Studies, 10 (3), 577-608. Doi, 10.22059/ijms.2017.231317.672627

Felo, A., Krishnamurthy, S. \& Solieri, S. (2003). Audit committee characteristics and the perceived quality of financial reporting, an empirical analysis. Working paper, Pennsylvania State University, Malvern, PA.

Fiador, V.O. (2013). Corporate governance and value relevance of financial information, evidence from the Ghana Stock Exchange. Corporate Governance, The international journal of business in society, 13 (2), 208-217, https,//doi.org/10.1108/14720701311316689.

Forbes, D. \& Milliken, F., (1999). Cognition and corporate governance, Understanding boards of directors as strategic decision-making groups. Academy of Management Review, 24 (3), 489-505.

Forker, J. (1992). Corporate governance and disclosure quality. Accounting and Business Research, 22 (86), 111-124.

Francis, J., R. LaFond, P. Olsson, \& K. Schipper. (2004). Costs of equity and earnings attributes. Accounting Review 79 (4), 967-1010.

Glaum, M. \& Street, D.L. (2003). Compliance with the disclosure requirements of Germany's new market, IAS versus US GAAP. Journal of International Financial Management Accounting, 14 (1), 64-100.

Habib, A., \& I. Azim. (2008). Corporate governance and value-relevance of accounting information, Evidence from Australia. Accounting Research Journal 21 (2), 167 -194.

Haniffa, R.M. \& Cooke, T.E. (2002). Culture, corporate governance, and disclosure in Malaysian corporations. Abacus, 38 (3), 317-349.

Hassan, M.S, M. Percy, \& J. Steward. (2006). The value relevance of fair value disclosures in Australian firms in the extractive industries, Asian Academy of Management Journal of Accounting and Finance, 2 (1), 41-46.

Ho, S. \& Wong, K. (2001). A study of the relationship between corporate governance structures and the extent of voluntary disclosure. Journal of International Accounting, Auditing, and Taxation, 10 (2), 139-156. 
Hodgdon, C., Tondkar, R.H., Adhikari, A. \& Harless, D.W. (2008). Compliance with IFRS disclosure requirements and individual analysts forecast errors, Journal of International Accounting, Auditing, and Taxation, 17 (1), 1-13.

Hodgdon, C., Tondkar, R.H., Adhikari, A. \& Harless, D.W. (2009), Compliance with international financial reporting standards and auditor choice, new evidence on the importance of the statutory audit, The International Journal of Accounting, 44 (1), 33-55.

Holtz, L. \& A.S. Neto. (2014). Effects of Board of Directors' Characteristics on the Quality of Accounting Information in Brazil. Revista Contabilidade Finanças, 25 (66), 255-266.

Hung, M., \& K. R. Subramanyam. (2007). Financial statement effects of adopting International Accounting Standards, the case of Germany. Review of Accounting Studies, 12 (4), 623-657.

IAS Regulation. (2014). A review of the literature on the impact of the mandatory adoption of IFRS in the EU, available at http,//ec.europa.eu/finance/accounting/.../141024-document-impact_en.pdf.

Ibanichuka, EA \& Briggs, AC. (2018). Audit reports and value relevance of accounting information, evidence from commercial banks in Nigeria. Indian Journal of Finance and Banking, 2 (1), 44-62.

International Accounting Standard Board (IASB). (2018). Conceptual Framework for Financial Reporting. IFRS Foundation.

Jarva, H., \& A.M. Lantto. (2012). The value-relevance of IFRS versus domestic accounting standards, evidence from Finland. The Finnish Journal of Business Economics, 2 (Juni), 141-177.

Jeanjean, T., \& H. Stolowy. (2008). Do accounting standards matter? an exploratory analysis of earnings management before and after IFRS adoption. Journal of Accounting and Public Policy, 27 (6), 480-494.

Juhmani, O. (2017). Corporate governance and the level of Bahraini corporate compliance with IFRS disclosure, Journal of Applied Accounting Research, 18 (1), 22 - 41.

Khidmat, W.B., M. Wang, \& S. Awan. (2018). Corporate governance, earnings management and the value relevance of accounting information, Evidence from Pakistan, International Journal of Financial Engineering, 05 (03), 1850025. https://www.worldscientific.com/toc/ijfe/05/0310.1142/S2424786318500251.

Kiel \& Nicholson. (2003). Board composition and corporate performance, how the Australian experience informs contrasting theories of corporate governance. Corporate Governance, An International Review, 11 (3), 189-205.

Kim, J., \& H. Shi. (2007). International Financial Reporting Standards, institutional infrastructures and costs of equity capital around the world. Working paper, Concordia University, and Hong Kong Polytechnic University.

Klein, A. (2002). Economic determinants of audit committee independence. The Accounting Review, 77 (2), 435-452.

Kothari, S. P., A. J. Leone, \& C. Wasley. (2005). Performance matched discretionary accrual measures. Journal of Accounting and Economics, 39 (1), 163-197

Krismiaji, Y A. Aryani, \& D. Suhardjanto. (2016). International Financial Reporting Standards, board governance, and accounting quality - A preliminary Indonesian evidence. Asian Review of Accounting, 24 (4), 474-497.

Landsman, W. R., E.L. Maydew, \& J.R. Thornock. (2012). The information content of annual earnings announcements and the mandatory adoption of IFRS. Journal of Accounting Economics, 53 (1-2), 34-54.

Linda. (2018). The analysis of corporate governance on the value relevance of accounting information. Thesis, Universitas Atma Jaya Yogyakarta.

Makhija, A.K. \& Patton, J.M. (2004). The impact of firm ownership structure on voluntary disclosure, empirical evidence from Czech annual reports. The Journal of Business, 77 (3), 457-491.

Mbobo, M.E. \& A.O. Umoren. (2016). The influence of audit committee attributes on the quality of financial reporting, evidence from Nigerian banks. International Journal of Economics, Commerce, and Management, 4 (7), 116-141.

Menon, K. \& Williams, J.D. (1994). The use of audit committees for monitoring. Journal of Accounting and Public Policy, 13 (2), 121-139.

Morck, R., A. Shleifer, and R. W. Vishny. (1988). Management ownership and market valuation. Journal of Financial Economics, 20 (January), 293-315. doi:10.1016/0304-405x(88)90048-7. http://dx.doi.org/10.1016/0304405X(88)90048-7.

Mungly, Y., RB. Bahajee, NP Maraye, K. Setah, \& Ramdhany. (2016). A study on corporate governance and value relevance of accounting information, Evidence from Listed companies in Mauritius, Proceedings of the 
Fifth Asia-Pacific Conference on Global Business, Economics, Finance and Social Sciences (AP16Mauritius Conference) Port Louis, Mauritius,

Nelson, J., Gallery, G. \& Percy, M. (2010). Role of corporate governance in mitigating the selective disclosure of executive stock option information, Accounting Finance, 50 (3), 685-717.

Nugroho, N.A., \& S.E. Hatane. (2017). Pengaruh board independent terhadap value relevance dengan intellectual capital disclosure sebagai variabel mediasi pada perusahaan manufaktur di Indonesia. Business Accounting Review, 5 (2), 577-588.

Owusu-Ansah, S. \& Yeoh, J. (2005). The effect of legislation on corporate disclosure practices. Abacus, 41 (1), $92-$ 109.

Paananen, M. (2008). The IFRS adoption's effect on accounting quality in Sweden. Working paper, University of Hertfordshire.

Paananen, M., \& Lin, C. (2009). The Development of accounting quality of IAS and IFRS over time, The case of Germany. Journal of International Accounting Research, 8 (1), 31-55.

Pearce, J. A., \& Zahra, S. A. (1992). Board composition from a strategic contingency perspective. Journal of management studies, 29(4), 411-438.

Pope, P.F., \& McLeay, S.J. (2011). The European IFRS experiment, objectives, research challenges and some early evidence. Accounting and Business Research, 41 (3), 233-266.

Pratiwi, A.D., Sutrisno, \& A.F. Rahman. (2019). Role of corporate governance in increasing the value relevance of earnings and fair value measurement of the non-financial asset in Indonesia company. International Journal of Multicultural and Multireligious Understanding, 6 (1), 91-100. http,//dx.doi.org/10.18415/ijmmu.v6i1.507

Rahman, R. A., \& Ali, F. H. M. (2006). Board, audit committee, culture and earnings management: Malaysian evidence. Managerial auditing journal, 21(7), 783-804. doi:10.1108/02686900610680549.

Ramsay, I. (2001). Independence of Australian company auditors, review of current Australian requirements and proposals for reform, Commonwealth of Australia, ACT, Canberra.

Raymond S.Y. Chan, Charles K.S. Lau, \& Artie W. Ng, (2011). Compliance and value relevance of audit committees, evidence from Hong Kong, Journal of Financial Reporting and Accounting, 9 (1),74-97, https,//doi.org/10.1108/19852511111139813.

Ruan, W., G.Y. Tian, \& S. Ma. (2011). Managerial Ownership, Capital Structure, and Firm Value, Evidence from China's Civilian-run Firms. Australasian Accounting, Business, and Finance Journal, 5(3), 73-92.

Sabia, M. \& Goodfellow, J. (2003). Integrity in the Spotlight, Opportunities for Audit Committees. The Canadian Institute of Chartered Accountants, Toronto, December.

Sales, J.B., Behnamoon, J., \& Hoseinzadegh, GH. (2013). Board of directors characteristics and value relevance of accounting information in Tehran Stock Exchange (TSE), Journal of Accounting Knowledge and Management Auditing, 2 (6), 51-63.

Samaha, K., Dahawy, K., Hussainey, K. \& Stapleton, P. (2012). The extent of corporate governance disclosure and its determinants in a developing market, the case of Egypt. Advances in Accounting, 28 (1), 168-178.

Saseela, S. (2018). Audit Committee and Value Relevance of Accounting Information of Listed Hotels and Travels in Sri Lanka. Asian Journal of Finance Accounting, 9(2), 387-398. 10.5296/ajfa.v9i2.12290.

Siekkinen, J. (2016). Board characteristics and the value relevance of fair values. Journal of Management Governance. 21 (2), 435-471.

Shamki, D. \& A.A. Ali. (2015). Ownership Structure Impacting Value Relevance of Accounting Information. International Journal of Emerging Research in Management Technology, 4 (1), 5-11.

Smith, R. (2003). Audit committees, combined code guidance report, Financial Reporting Council, London.

Street, D. L., Gray, S. J., \& Bryant, S. M. (1999). Acceptance and observance of international accounting standards: An empirical study of companies claiming to comply with IASs. The International Journal of Accounting, 34(1), $11-48$.

Street, D.L., \& Gray, S.J. (2002). Factors influencing the extent of corporate compliance with international accounting standards, a summary of a research monograph. Journal of International Accounting, Auditing, and Taxation, 11 (1), 51-76. 
Tarca, A., (2004). International convergence of accounting practices, choosing between IAS and US GAAP. Journal of International Financial Management and Accounting 15 (1), 60-91.

Tshipa, J., Brummer, L., Wolmarans, H., \& Du Toit, E. (2018). The impact of flexible corporate governance disclosures on value relevance. Empirical evidence from South Africa. Corporate Governance: The International Journal of Business in Society, 18(3), 369-385. https:/ / doi.org/10.1108/CG-05-2017-0106

Umoren, A.O. \& E.R. Enang. (2015). IFRS adoption and value relevance of financial statements of Nigerian listed banks. International Journal of Finance and Accounting, 4(1), 1-7. doi:10.5923/j.ijfa.20150401.01.

United Nations Conference on Trade and Development. (2006). Guidance on good practices in corporate governance disclosure, United Nations Conference on Trade and Development, New York, NY.

Usman, A.B., N.A. Amran, \& H. Shaari. (2017). The effect of corporate governance mechanisms on the valuation of comprehensive income reporting in Nigeria, Malaysian Management Journal, 21 (December), 33-47.

Verriest, A., Gaeremynck, A., \& Thornton, D.B. (2013). The impact of corporate governance on IFRS adoption choices. European Accounting Review, 22 (1), 39-77.

Warfield, T.D., J. J. Wild, \& K. L. Wild. (1995). Managerial ownership, accounting choices, and informativeness of earnings. Journal of Accounting and Economics, 20 (1), 61-91. doi:10.1016/0165-4101(94)00393-J.

Whelan, C. (2008). The value-relevance of corporate governance, Australian evidence. Corporate Ownership and Control, 4 (4), 292-300. 6. 10.22495/cocv6i1c2p6.

Williamson, O.E. (1984). Corporate governance. Yale Law Journal, 93 (7), 1197-1230.

Yermack, D. (1996). The higher market valuation of companies with a small board of directors. Journal of Financial Economics, 40 (2), 185-211. 